\title{
Electroconvulsive therapy: historical construction of nursing care (1989-2002)
}

\author{
Eletroconvulsoterapia: construção histórica do cuidado de Enfermagem (1989-2002)
}

Terapia electroconvulsiva: construcción histórica del cuidado de enfermería (1989-2002)

\section{Juliana Cabral da Silva Guimarães', Bárbara Lima dos Santos', Pacita Geovana Gama de Souza Aperibense', Gizele da Conceição Soares Martins', Maria Angélica de Almeida Peres', Tania Cristina Franco Santos'}

'Universidade Federal do Rio de Janeiro, Anna Nery Nursing School. Rio de Janeiro, Rio de Janeiro, Brazil.

\section{How to cite this article:}

Guimarães JCS, Santos BL, Aperibense PGGS, Martins GCS, Peres MAA, Santos TCF. Electroconvulsive therapy: historical construction of nursing care (1989-2002). Rev Bras Enferm [Internet]. 2018; 71(Suppl 6): 2743-50. [Thematic Issue: Good practices in the care process as the centrality of the Nursing] DOI: http://dx.doi.org/10.1590/0034-7167-2018-0168

Submission: 05-18-2018 Approval: 07-12-2018

\begin{abstract}
Objective: to describe the nursing care performed by the nursing team to the person with mental disorder submitted to ECT and to analyze the implications of the Psychiatric Reform in this care. Method: socio-historical study, which uses the Thematic Oral History method. Results: the nursing team is present in a continuous way in the monitoring of people submitted to ECT, performing care before, during and after the same, as well as visualizing the evolution of the technique and also of nursing care itself, however, does not recognize the Psychiatric Reform as agent for this change. Final considerations: the Brazilian Psychiatric Reform triggered a process of humanization of nursing knowledge, influencing the care of the person with mental disorder submitted to ECT, with this, care practices also changed, a law was approved, regulating its practice, and its application was decreasing.
\end{abstract}

Descriptors: Electroconvulsive Therapy; History of Nursing; Psychiatric Nursing; Nursing Care; Nursing.

\section{RESUMO}

Objetivo: descrever o cuidado de Enfermagem realizado pela equipe de Enfermagem à pessoa com transtorno mental submetida à ECT e analisar as implicações da Reforma Psiquiátrica nesse cuidado. Método: estudo sócio-histórico, que utiliza o método da História Oral Temática. Resultados: a equipe de Enfermagem se faz presente de forma contínua no acompanhamento das pessoas submetidas à ECT, realizando cuidados antes, durante e após a realização da mesma, bem como visualiza a evolução da técnica e também do cuidado de Enfermagem em si, contudo, não reconhece a Reforma Psiquiátrica como agente formador desta mudança. Considerações finais: a Reforma Psiquiátrica brasileira desencadeou um processo de humanização do saber de Enfermagem, influenciando no cuidado à pessoa com transtorno mental submetida à ECT, com isso, as práticas assistenciais também sofreram alteração, uma lei foi aprovada, regulamentando a sua prática, e sua aplicação foi diminuindo.

Descritores: Eletroconvulsoterapia; História da Enfermagem; Enfermagem Psiquiátrica; Cuidado de Enfermagem; Enfermagem.

\section{RESUMEN}

Objetivo: describir el cuidado de Enfermería realizado por el equipo de Enfermería a la persona con trastorno mental sometido a la TEC y analizar las implicaciones de la Reforma Psiquiátrica en ese cuidado. Método: estudio socio-histórico, que utiliza el método de la Historia Oral Temática. Resultados: el equipo de Enfermería se hace presente de forma continua en el acompañamiento de las personas sometidas a la TEC, realizando cuidados antes, durante y después de la realización de la misma, así como visualiza la evolución de la técnica y también del cuidado de Enfermería en sí, sin embargo, no reconoce la Reforma Psiquiátrica como agente formador de este cambio. Consideraciones finales: la Reforma Psiquiátrica brasileña desencadenó un proceso de humanización del saber de Enfermería, influenciando en el cuidado a la persona con trastorno mental sometido a la TEC, con eso, las prácticas asistenciales también sufrieron alteración, una ley fue aprobada, regulando su práctica, y su aplicación fue decreciente.

Descriptores: Terapia Electroconvulsiva; Historia de la Enfermería; Enfermería Psiquiátrica; Cuidado de Enfermería; Enfermería. 


\section{INTRODUCTION}

The traditional psychiatry model, which lasted until the second half of the twentieth century in Brazil, had as its main characteristic the maintenance of the person with mental disorder excluded from society, since rehabilitation was not a longing for this care model. The care of Psychiatric Nursing, in turn, was not qualified, being performed, in most institutions, by religious, practical nurses, auxiliaries and nursing assistants, depending on the season ${ }^{(1)}$.

Among the different forms of treatment for mental disorders, we highlight convulsive techniques, originated in the asylum model. Convulsive therapy of biological origin arose from an experiment carried out in 1934 by the Hungarian neuropsychiatrist, Ladislas Joseph von Meduna, who observed a decrease in psychotic symptoms in epilepsy induced by seizures ${ }^{(2)}$.

Initially, seizures were triggered by the administration of drugs such as Camphor and Pentylenetetrazol (cardiazol), however, it was a difficult to control method, since it was not possible to predict when the seizure would start and cease. In 1937, two Italian neuropsychiatrists used electricity for the first time to trigger the seizure ${ }^{(2)}$.

The technique of electroconvulsive therapy (ECT) has replaced the technique of using pharmacology to induce seizures in the treatment of psychoses, since it offers greater control over seizures. It was between the 1950s and 1970s that ECT was consecrated as the most used therapeutic strategy in Brazilian psychiatric institutions, applied to the most different types of psychiatric diagnoses, although its mechanism of action, as well as its therapeutic indications were not fully determined ${ }^{(2-3)}$.

Clarifying the procedure, during the passage of electrical current in the brain occurs loss of consciousness as well as generalized muscle spasm. The tonic, clonic and finally comatose stages are the same as a pathological convulsive crisis. Next, there is a few minutes' sleep, from which the person with a mental disorder submitted to ECT awakens spontaneously, most of them without remembering what happened ${ }^{(3)}$.

In the late 1970s, with the aim of denouncing the poor quality of psychiatric care and encouraging discussions about it in a struggle for more humane and less segregating and violent care, the Mental Health Workers' Movement (MTSM- Movimento dos Trabalhadores de Saúde Mental), an event considered to be a forerunner of the Brazilian Psychiatric Reform movement, which was fighting for a change in the model of attention and management in Mental Health ${ }^{(4-5)}$.

In addition, the Psychiatric Reform movement, which received many gains from the Sanitary Reform movement, aimed to implement and enable new proposals for therapeutic care for the person with mental disorder to ensure and guarantee their rights and their autonomy. Its principles are deinstitutionalisation, dehospitalisation and social reintegration, thus forming the pillar of the new care in Mental Health ${ }^{(6)}$.

The 1980 s were marked by events of national repercussion, such as the VIII National Health Conference (Conferência Nacional de Saúde), the $1^{\text {st }}$ National Conference on Mental Health (Conferência Nacional de Saúde Mental) and the II National Congress of the MTSM (Congresso Nacional do MTSM), which encouraged political discussions about the model of psychiatric care and its negative effects on society. In addition to this, in 1989 the Bill 3657/1989 of the Representative Paulo Delgado, of the Workers' Party of Minas Gerais (Partido dos Trabalhadores de Minas Gerais), was passed to the National Congress, which provided for the progressive extinction of asylums and their replacement by others care resources and regulation of compulsory psychiatric hospitalization, establishing that psychiatric hospitalization would only be indicated in view of the insufficiency of extra-hospital resources ${ }^{(5)}$.

However, only in 2001, the Paulo Delgado Law (Lei Paulo Delgado ) 10.216 was sanctioned in the country, with several amendments to the original Bill, but pointed to the redirection of Mental Health care, favoring the offer of treatment in communitybased services and the guarantee of the rights of persons with mental disorders, but did not establish clear mechanisms for the progressive extinction of asylums ${ }^{(5)}$. Despite the political changes, the psychiatric hospital has undergone restructuring, aiming that it becomes a therapeutic device while the extrahospital network of psychosocial attention is structured ${ }^{(7)}$.

In this way, changes were imposed on Mental Health Care services, but mental health practices were still present in psychiatric hospitals, as it was necessary for society and health professionals to join in to change the way they think and act on the treatment pipelines. Regarding ECT, the beginning and strengthening of the Brazilian Psychiatric Reform was an important factor for its decline, since it had also become a technique mistakenly used as a punitive instrument and without any therapeutic discrimination in previous decades.

In 2002, the Federal Council of Medicine (CFM- Conselho Federal de Medicina), in order to recognize the importance of this therapeutic technique, and regulate its application, as well as the care that should be used during treatment, approved Resolution 1.640, subsidized by Law $10.216 / 01$. The importance of the Nursing team before, during and after ECT is evidenced by their continuous stay in the follow-up of the person with mental disorder submitted to this technique ${ }^{(8)}$.

The Brazilian Psychiatric Nursing, which appears for the society in the nineteenth century, in the interior of the asylum, still in its pre-professional phase, had its trajectory marked by the performance in psychiatric institutions, where it provided basic care (food, hygiene, medication administration, dressings, etc.) and almost never care of Psychiatric Nursing aimed at the rehabilitation of the person with mental disorder, as specific therapeutic practices for psychosocial rehabilitation ${ }^{(9)}$.

This difficult phase of updating the practices of Psychiatric Nursing is understood by the fact that controlling, monitoring and repressing were the main characteristics of Nursing care, which refers to traditional psychiatric care, in which the focus was to maintain order in asylum ${ }^{(10-11)}$. The first nurses specializing in Psychiatric Nursing graduated only in the 1950s and 1960s, and the process of training nursing team in this area was slow, which made it difficult to carry out approaches outside the asylum logic ${ }^{(9)}$.

Thus, the psychiatric hospital/asylum was an obscure place, where the nursing team had a knowledge/power built over time by their continuous stay and practical experience, where ECT emerged and remained as an effective technique for reduction of symptoms such as delusions, hallucinations and episodes 
of self and hetero-aggressive behaviors, among others called psychotic symptoms ${ }^{(3)}$.

Therefore, this study aims at nursing care to the person with mental disorder submitted to ECT, during the Brazilian Psychiatric Reform movement. The initial time frame was the year 1989, when Bill 3657/1989 was sent to the National Congress, representing for the time a victory in the legislative and normative field of the Psychiatric Reform movement. The final mark corresponds to the year of ECT regulation by CFM through Resolution 1640 of 2002, meeting the requirements of the Psychiatric Reform Act for a more dignified and respectful care for the person with mental disorder.

The study is justified by the need to know excerpts from the history of Psychiatric Nursing about ECT, since this technique remains active until the present day with the nursing team that is part of the procedure. Studying the transformations of the care of Psychiatric Nursing in the last decades allows raising several reflections on nursing care.

It is considered relevant that the practices, during the period studied, reflect the desire for change driven by the Brazilian Psychiatric Reform movement, since it broke with the asylum model and with the previously taught practices and, through searches conducted in the literature, the scarcity of studies carried out by nurses on the subject in Brazil.

\section{OBJECTIVE}

To describe the nursing care performed by the nursing team to the person with mental disorder submitted to ECT and to analyze the implications of the Psychiatric Reform in this care.

\section{METHOD}

\section{Ethical aspects}

The project that led to the study was approved by the Research Ethics Committee of the Escola de Enfermagem Anna Nery/Instituto de Atenção à Saúde São Francisco de Assis/ Universidade Federal do Rio de Janeiro. The methodology was guided by Resolution 466/2012 of the National Health Council (Conselho Nacional de Saúde). The Free and Informed Consent Form (ANNEX B) was presented to the employees before the interviews were conducted, and all the doubts that they presented about the research and its participation were resolved.

All care to reduce any potential risks of this research was taken so that there was no emotional damage or embarrassment during the interview. The authors of the study pledged to ensure the integrity and well-being of the research participants, respecting cultural, social, moral, religious and ethical values, as well as the habits and customs of the participants.

\section{Type of study}

Socio-historical research, of a qualitative nature and developed from the perspective of the History of Present Time, in which the researcher must incorporate history into the present of societies, from current categories and references, since it is contemporary with its object of study. Thus, search based on a supposed past, guidelines for the future itself ${ }^{(12-13)}$.

\section{Methodological procedures}

Historical sources were written and oral documents. Written documents, considered primary sources, were located in specific sites, such as the Brazilian Federal Revenue and in sites accessing the legislation. Primary oral sources were produced through the technique of Thematic Oral History, a research method that uses the technique of interviewing and other procedures articulated among themselves in the record of human experience narratives. The Oral History is a resource that goes beyond a means of access to knowledge and information, being a resource of transformation ${ }^{(13)}$.

\section{Study setting}

The present research had as a research setting the psychiatric institutions of the city of Rio de Janeiro, since the possible modifications in the discourse of Nursing from the Psychiatric Reform may have directly affected nursing care in the area.

\section{Data source}

Law 10.216/01, Bill 3657/89 and Resolution of the Federal Council of Medicine (CFM) 1640/02 were selected as the primary sources for the research. The secondary sources were articles, theses and books on the subject.

The research researchers were nurses, technicians and nursing assistants who worked in psychiatric institutions in the city of Rio de Janeiro. We included those who experienced in their professional trajectory, during the movement of Psychiatric Reform, nursing care to the person with mental disorder submitted to ECT; were excluded those who did not present memory or health preserved to participate in the study.

\section{Collection and data organization}

The data collection was carried out from April to June 2015. The oral documents were collected through semi-structured interviews, previously scheduled with the employees by telephone, according to their preference of date, time and place for the accomplishment, at no cost to the employee. The interviews were recorded through two digital recorders and later transcribed, a process of textualizing recorded speech. After being transcribed, they were delivered to the researchers for validation and authorization of their use in the research.

There were 6 employees, including 3 nurses, 1 nursing technician and 2 nursing assistants. In order to ensure employees' privacy, they were identified by the initial letter of the profession followed by the ordinal number corresponding to the order of the interviews (Ex: N1 $=$ nurse $1, \mathrm{NA} 2=$ nursing assistant $2, \mathrm{NT} 3=$ nursing technician 3 ).

\section{Data analysis}

The analysis was based on the historical research method, which prioritizes the internal and external criticism of the documents, followed by triangulation of the data, which makes it possible to arrive at a version of the historical fact. Data from primary and secondary sources were compared chronologically and thematically. It is important to emphasize that the term "patient" will appear in the extracts of the interviews, since the researchers thus denominated the people with mental disorder in their speeches. The interpretation of the data was made in a correlation between the facts described and the existing scientific 
literature. The emergent themes from the data analysis were: nursing care for the person with mental disorder during ECT; and Psychiatric Reform in Brazil: implications for nursing care.

\section{RESULTS}

Nursing care for the person with a mental disorder submitted to electroconvulsive therapy

The care provided by the nursing team before ECT was similarly described by the different researchers. According to the reports, it basically consisted of: leaving the patient fasted, checking the vital signs, removing the prostheses and/or adornments, as we observe below:

Before, the patient had to be fasting for 4 hours because it was always performed in the morning, around 7am. (NT1)

We would send the patient to the room, tell him that he was going to take it, ask him to go to the bathroom to urinate, not to have sphincter release and to take it. There we would take prosthetics, take out props, position him straight, roll the fabric for him to bite and hold the main joints. (EN2)

Fasting is an important care and it is the responsibility of nursing to assure it, despite the difficulty to do so. This difficulty evidenced in other research is confirmed in this study, since it was also reported by the researchers:

In the morning, he/she [patient] did not eat breakfast, but you had to have someone already assigned to walk behind the patient. Because ECT indication was usually for restless patients. One person [from the nursing team] was watching this patient, not letting him/her to drink water, etc.... (N3)

There is a lot of resistance from the patient to ECT and we have to keep fasting. This is the biggest difficulty because most of the time, until today, we have to keep restraint so that he/she [patient] does the fasting. (NA1)

The reference to restraint, although not explicit of what kind, is cited as a nursing care to the person to be submitted to ECT. However, in the context of the researcher's speech it seems to be a measure to force the person to perform the procedure, although it is accompanied by expressions such as "to talk" and "to try", which demonstrate a care that is attempted to humanize, but which is still imbued with the asylum model.

Regarding nursing care at the time of ECT, the actions of nursing professionals consisted in immobilizing the person with mental disorder, as can be observed in the following reports:

At the time of ECT, one person held his arms and torso so that he would have his limbs close to his body at the time of the seizure to prevent injury and the other person holding the lower limbs. Then the doctor came with ECT device, put the two electrodes on and the patient convulsed. (NT1)

Then we would make a roll of gauze for the patient to bite ... he would lie down, bite that gauze, and we, from Nursing, would hold the main joints, shoulder, hip, and legs. We held it so that when the tonic contraction came, it would not fracture any bone. (N2)

It is imperative to make explicit the importance and necessity of specialized nursing care, since there are specific needs fundamental for therapeutic success and for the prevention of damages, as well as for the good recovery of people undergoing this technique. However, in the statements of the researchers it is not observed the valuation of this care in their specificities:

When that happened, when he came back from the crisis, we went to bed, waited for him to wake up. (N2)

It was more observation, we put him on the bed and he slept, and woke up well. Then when the patient returned from ECT and woke up, we would have breakfast in the morning, because we had to keep their fast before. (NA2)

After some patients still get a little debilitated, because they become sleepy. So it's actually giving comfort. Because some do not remember what happened. (N1)

The presence of the nursing team during all stages of ECT and the relevance of their care to the therapeutic efficacy of the same, as observed in the analysis of the study, rectifies the importance of building knowledge in Psychiatric Nursing in this context, in order to influence the transformations necessary for the quality of this technique.

\section{The Psychiatric Reform and its implications for nursing care in this context}

Even though it was an era in which the Brazilian Psychiatric Reform was already strengthened, it is possible to perceive the relationship between ECT practice and asylum practices, although the reports of the researchers, in their majority, affirm a positive evaluation of the technique, as we observed in the following reports:

I think it's an aggressive procedure. You stimulate a seizure is an aggression, but in particular, it left me in doubt at times. Although I saw it as an aggression on some patients we saw a response to it. We saw an improvement. (N1)

Look, at the beginning it is quite shocking, then you already take it as a routine. At that moment he does not understand, he will understand later that this is the only resource he still has to return home. But at that moment it is very aggressive. (NA1)

Always tense, scared, but I've always seen the patient to improve. So if you ask me if I raise the hat to the ECT, I say I do. Because I've seen a lot of people get out of these pictures with ECT. And we were not quiet at the time, because everyone was very afraid of ECT, for being a scary thing. (N3)

It should be noted that the expressions "aggressive", "tense" and "shocking" mentioned by the researchers point to a technique that, besides requiring the preparation of the nursing team to provide care to the person with mental disorder submitted to it, reaffirms the relationship with asylum practices and their stigmas.

An important implication of the Psychiatric Reform reported by the study's researchers was the limitation of the prescription of ECT by the medical team: 
I saw that more and more ECT prescriptions were decreasing, right ... It arrived at a point that was only asked for very serious cases, in the beginning it was an indiscriminate thing. (NA2)

And ECT was practically abolished, but they still did in very few patients. (NT1)

As like any other therapy, ECT should be prescribed by the physician and its choice should be based on the advantages and disadvantages of other possible and available treatment options.

From the talk of the researchers, there are more changes coming from Psychiatric Reform in ECT:

Now it has an entire room monitored with defibrillator, with monitor, with everything and is done with anesthetist. (EN2)

The procedure would be all protocol, according to all the required SOPs, it was a very serious thing. (N3)

She [the nursing chief] struggled so that if she had a suitable room, resources for the patient, so that he could also do, anesthetized, so that the suffering would be less. (N1)

Resolution 1,640/02 makes it compulsory in its Article 5 for the clinical evaluation in the pre ECT, especially regarding cardiovascular, neurological, respiratory, osteoarticular and dental conditions. In addition, minimal laboratory tests should be required, such as hemogram and electrolytes, as well as electrocardiogram (ECG).

Nowadays, before, an evaluation is done, an electro [ECG], to know the physiological conditions of the patient. (NA1)

The researchers identified change in theoretical discourse, but did not identify the influence of Psychiatric Reform in their work context:

I think the reform did not influence ECT. I think that, over the years, with the technologies that we have, we have been looking for better things to improve and evolved. (N2)

I don't think that much has changed... (NT1)

I haven't seen any change. This Psychiatric Reform, for me, I see nothing. (NA1)

It is analyzed that, at the same time that they refer to changes in care in ECT, since its normalization, nursing professionals do not recognize such changes as coming from Psychiatric Reform. However, the change in care practices in relation to ECT, which have become more elaborate, grounded, humanized, as described by the employees, is notorious, and does not perceive them as a consequence of the Reform, demonstrating the need for professional training, with emphatic disclosure of the renewed policies, so that the professionals are actually part of the changes in the Mental Health services, providing adequate care to people submitted to ECT.

\section{DISCUSSION}

The importance of the Nursing's role for the therapeutic efficacy of ECT is significant, since it is up to these professionals to take care of the preparation, the application and the subsequent moment of this technique. Since ECT was only regulated in 2002, the nursing team built, in the course of their professional practice, knowledge and strategies for the care of the person with a mental disorder submitted to ECT.

To keep the fast is a nursing care that is not simple, since ECT prescription in general caused a lot of anxiety and fear in the person with mental disorder, which required a follow-up so that fasting would not be broken. The emotional effects generated before the performance cause fear in the moments that precede it, requiring of the nursing team a positive attitude, helping the person to control their anxiety, aiming at the acceptance of the treatment ${ }^{(3)}$.

Mechanical and chemical containment methods were, at the time, widely used in the practice of Psychiatric Nursing, a practice that was representative of the asylum model applied when the person with mental disorder showed excessive aggression, behaved in an unruly manner and did not accept the proposed treatment. Currently, the use of this practice is still observed ${ }^{(14)}$.

Mechanical restraint consists in keeping the person with a mental disorder physically trapped and should be used to limit impulses, both physical and emotional. Examples of mechanical containments include: bandaging, straitjackets, cells, and containment with a sheet. Chemical restraint, in turn, is characterized by the use of medication to control aggression, through alteration of cerebral biochemistry, when verbal management with the person with mental disorder in crisis is not possible $\mathrm{e}^{(13-14)}$.

It is important to emphasize that such methods are not recognized as nursing care, due to the difficulty in justifying their efficacy, added to the negative stigma of a punitive procedure coming from Asylum Psychiatry ${ }^{(13-14)}$. Containment for the maintenance of fasting for ECT therefore does not affect respect for the rights of the person with mental disorder to decide on their treatment as provided in the Psychiatric Reform legislation.

With regard to the other mentioned care, it is evident that the removal of prostheses, usually dental, and props (glasses, watches and others), are precautionary measures to facilitate emergency interventions in case of intercurrences during ECT.

The request for the person to use the toilet before performing the technique is also a precautionary measure to avoid bladder and/or intestinal elimination, in large quantity, due to the common sphincter relaxation during ECT, which causes a seizure in which the clonic phase is characterized by periodic contractions interspersed with periods of relaxation, in which "If the bladder is full of urine then there may be a urinary incontinence and emptying of the same".

In addition to these precautions, the bath was also mentioned before the procedure to remove oil from the skin, which is also a precautionary measure, this, to facilitate interventions such as cardiac monitoring of the person undergoing ECT, when it is necessary to place electrodes in your body.

It is also important that the hair is clean and dry, that the medicines of continuous use of the morning are maintained and that the water intake is restricted to the minimum possible, besides the orientation so that the person empties the bladder before the accomplishment of the technique ${ }^{(8)}$.

Having a professional exclusively to perform nursing care at the time of the ECT demonstrates the importance of having a 
specific preparation for follow-up of this. However, the researchers did not mention this need, which shows that this is not perceived by the nursing team, and ECT is seen as a technique that requires low complexity care, which is not true when we take into account its practice in a period in which it was not regulated and, therefore, raised the possibilities of side effects.

The triggered seizure is of the tonic-clonic type, characterized by an intense contraction of the whole musculature of the individual, which lasts a few moments and constitutes the tonic phase; a periodic contraction is followed by a period of prolonged relaxation, which is the clonic phase. These are the critical phases that require more attention from the team involved. After these phases, muscle relaxation occurs, where there may be release of the sphincters, which is maintained for a few minutes, being considered a postcritical phase, which precedes the final recovery ${ }^{(15)}$.

Due to vigorous muscle contractions resulting from the tonicclonic seizure, there is a risk of orthopedic injuries, especially in the temporomandibular and scapulohumeral joints. Thus, it was necessary that the nursing professionals present at the time of ECT were responsible for the physical containment of these members, holding them to move as little as possible, avoiding damages to the person during the technique.

The cardiovascular stimuli caused by ECT, related to the induction of an electric discharge, occur through the vagus nerve and extend to the Parasympathetic and Sympathetic System. ECT stimulus causes activation of the Parasympathetic System causing bradycardia and lowering of blood pressure and, consequently, activation of the Sympathetic System, causing opposing effects such as: increase in blood pressure, heart rate and an overall increase in cardiac output ${ }^{(2)}$. These effects may lead to cardiorespiratory arrest and, therefore, the nursing team should closely observe these parameters, since the side effects of ECT are generally transient and benign, however, most cases of death related to ECT are of cardiovascular origin ${ }^{(16)}$.

Finally, regarding the care after ECT, the researchers cited: observation of the patient to avoid falls, lateral positioning to prevent bronchoaspiration due to excessive salivation or in case of emesis, verification of vital signs for control of basic body functions such as blood pressure, heart rate, breathing rate, and body temperature.

Thus, the post ECT care described required a nursing care attentive to the vital signs and other signs of discomfort that the person with mental disorder could present. Continuous evaluation of patient behavior and improvement record records help determine the number of sessions required, as well as analyze the therapeutic efficacy achieved ${ }^{(8)}$.

In the recovery room the person with mental disorder should be placed in the lateral decubitus for approximately 30 minutes and may present mental confusion and/or psychomotor agitation. Immediately after ECT, the professional should avoid questions so that the patient's memory is not forced and there is no discomfort and, when conditions are met, the diet should be offered. It is essential to perform the record of the procedure in the medical record, containing all relevant information on how ECT was performed, the physical state of the person with mental disorder and the intercurrences, if they occur ${ }^{(8)}$.

ECT faces many barriers due to its past, among them the strength of industry, comparison with other biological techniques originated at the same time as lobotomies and insulin shock, as well as its inheritance of a technique performed in mass without clinical evaluation and related to punishment of the person with mental disorder ${ }^{(8)}$.

To achieve the principles proposed by the Brazilian Psychiatric Reform movement, Laws and Resolutions were created to tailor care to the person with mental disorder, such as CFM Resolution $1.640 / 02$. The approval of this resolution caused changes both in ECT technique itself and in nursing care to the person with mental disorder submitted to it.

When well evaluated and discussed, ECT is an effective and safe technique, sometimes with minor damage and efficacy that is clearer than psychotropic drugs, and provides a rapid and necessary response in some cases ${ }^{(16)}$.

The use of anesthesia is mentioned by all the researchers in the research and is in compliance with Resolution 1.640/02 of CFM. Knowledge of the anesthetics used in the procedures, including ECT, such as its effects and the duration of the procedure, should be used to support the continuous assessment of the person being treated ${ }^{(17)}$. Continuous assessment is of paramount importance, mainly because it added to the risks of ECT, anesthetic risks.

In the context of the Brazilian Psychiatric Reform, Nursing started to perform a more care-oriented care management, such as providing all the necessary material, checking the availability of recent laboratory tests, testing and maintaining the equipment that is necessary during the performance of the technique ${ }^{(8)}$. In addition, the nursing team also started to carry out the work of monitoring vital signs, performing their registration before, during and after ECT, as well as the care already performed before the regulation by $\mathrm{CFM}^{(3,18)}$.

Rather than promoting clinical safety for ECT, the Brazilian Psychiatric Reform movement has given the person with mental disorder autonomy over their treatment and promoted strategies for their reintegration into society through the qualification of care, reducing indiscriminate hospitalizations and long duration $^{(5)}$. These characteristics were evidenced in Article 3 of CFM Resolution 1640/02, which made it obligatory to obtain written informed consent from the person with mental disorder before beginning the practice, thus guaranteeing their right to decide whether or not to perform ECT.

However, although there was a change in Psychiatric discourse due to Psychiatric Reform, the investment in structuring a substitute Mental Health network in psychiatric hospitals in 2009 was minimal, since hospitals still used $88 \%$ of the resources of the Unified Health System (SUS- Sistema Único de Saúde) for Mental Health, exemplifying the still existing contemplation of the traditional model ${ }^{(19)}$.

Although almost 40 years have passed since the beginning of the Psychiatric Reform movement, it is still necessary for its concepts to be applied in the daily work of Mental Health professionals in order to achieve a shift from the perspective of hospital intervention to extra- hospital devices ${ }^{(19)}$.

\section{Study limitations}

The stigma involved in the practice of ECT was set as a limitation of the study, since employees were inhibited by expressing 
themselves more openly to the facts they experienced. In addition to this, there is a shortage of nursing records on the specific care of people with mental disorders submitted to ECT technique also characterizing a limitation of the research.

\section{Contributions to Nursing, Health or Public Policy}

The study contributes to the research in Psychiatric Nursing and in the History of Nursing, since it reveals aspects related to nursing care to the person with mental disorder submitted to ECT, promoting the diffusion of knowledge from the disclosure of its results to society, in particular for the scientific community, adhering to the theme of the "National Agenda of Priorities in Health Research", as recommended by the Ministry of Health in its second item.

In addition, she provided the development of a research line at the Núcleo de Pesquisa de História da Enfermagem Brasileira (Nuphebras) of the Escola de Enfermagem Anna Nery (EEAN) of the Universidade Federal do Rio de Janeiro (UFRJ) concerning the History Care of the patient with mental disorder. In the care, you can raise reflections that will lead to new studies and possible transformations of the nursing practice, in order to meet the precepts of the Psychiatric Reform.

\section{FINAL CONSIDERATIONS}

The research made it possible to describe how nursing care was performed in the context of the Psychiatric Reform before the person with mental disorder before, during and after ECT, evidencing that the nursing team fulfilled its therapeutic role in the psychiatric institutions of the municipality of Rio de Janeiro, distancing itself from the asylum model.

The researchers pointed out that the accomplishment of ECT counted on the participation of one or more members of the nursing team. Care practices suffered alteration from the strengthening of the Brazilian Psychiatric Reform, breaking with the punitive character and mass treatment applied over the years.

The regulation of ECT practice has reduced its application, since criteria determine the choice of this type of treatment. In nursing care, based technical responsibilities, such as to ensure the physical integrity of the person with mental disorder, through physical examination and other specific care of preparation for ECT, prevention of damage during its implementation, nursing intervention in case of intercurrences and rehabilitation care in post ECT, making their presence essential for the best therapeutic use.

Thus, Nursing, together with other members of the health team, is responsible for implementing the changes foreseen by the Psychiatric Reform in favor of the care that has historically transformed the mental health care model. Finally, it is concluded that in spite of all the progress observed from the study, nursing professionals do not recognize the Brazilian Psychiatric Reform as a transforming agent of their care nor do they value the care provided before, during and after ECT, essential for the success of treatment with this therapy.

\section{REFERENCES}

1. Esperidião E, Silva NS, Caixeta CC, Rodrigues J. The Psychiatric Nursing, ABEn and the Scientific Department of Psychiatric and Mental Health Nursing: progress and challenges. Rev Bras Enferm[Internet]. 2013[cited 2017 Nov 08];66(Spe):171-6. Available from: http://dx.doi.org/10.1590/S0034-71672013000700022

2. Mankad MV, Beyer JL, Weiner RD, Krystal AD. Clinical Manual of Electroconvulsive Therapy. Washington, DC: American Psychiatric Publishing; 2010.

3. Borba LO, Guimarães AN, Mazza VA, Maftum MA. Treatment on hospital-centered model: perceptions of relatives and individuals affected by mental disturbance. Rev Enferm UER][Internet]. 2015[cited 2017 Nov 08];23(1):88-94. Available from: http://www.epublicacoes.uerj.br/index.php/enfermagemuerj/article/view/4689/12361

4. Maftum MA, Silva AG, Borba LO, Brusamarello T, Czarnobay J. Changes in professional practice in the mental health area against Brazilian Psychiatric Reform in the vision of the nursing team. Rev Pesqui: Cuid Fundam[Internet]. 2017[cited 2017 Nov 08];9(2):30914. Available from: http://seer.unirio.br/index.php/cuidadofundamental/article/view/3626/pdf_1

5. Brasil. Ministério da Saúde. Secretaria de Atenção à Saúde. DAPE. Coordenação Geral de Saúde Mental. Reforma psiquiátrica e política de saúde mental no Brasil. Documento apresentado à Conferência Regional de Reforma dos Serviços de Saúde Mental: 15 anos depois de Caracas. OPAS. Brasília, novembro de 2005.

6. Martins GCS, Moraes AEC, Santos TCF, Peres MAA, Almeida Filho AJ. The implementing process of therapeutic homes in Volta Redonda - Rio de Janeiro. Texto Contexto Enferm[Internet]. 2012[cited 2017 Nov 08];21(1):86-94. Available from: http://dx.doi. org/10.1590/S0104-07072012000100010

7. Souza EJ, Moreira LH, Cardoso MM, Ferreira RG, Silva TC. The formation of social reintegration strategies of the psychic suffering carrier: new directions for psychiatric nursing in Brazil. Iss Mental Health Nurs[Internet]. 2014[cited 2017 Sep 29];35(9):680-8 Available from: http://www.tandfonline.com/doi/abs/10.3109/01612840.2014.901451?journalCode =imhn20

8. Ávila MD. Eletroconvulsoterapia: da origem à aplicação modificada[Monografia][Internet]. Porto Alegre: Universidade Federal do Rio Grande do Sul; 2010[cited 2016 Sep 29]. Available from: http://hdl.handle.net/10183/24868

9. Silva BT, Guimarães JCS, Tarma GF, Santos TCF, Almeida Filho AJ, Peres MAA. Instituto de Psiquiatria da Universidade do Brasil as internship field of Escola Anna Nery (1954-1962). Esc Anna Nery[Internet]. 2017[cited 2017 Nov 08];21(3):e20160379. Available from: http://dx.doi.org/10.1590/2177-9465-ean-2016-0379 
10. Machado SC, Stipp MAC, Oliveira RMP, Moreira MC, Simões LM, Leite JL. Leadership in psychiatric nursing. Esc Anna Nery[Internet]. 2006[cited 2017 Nov 08];10(4):730-4. Available from: http://dx.doi.org/10.1590/S1414-81452006000400016

11. Bandeira PM, Souza CHP, Guimarães JCS, Almeida Filho AJ, Peres MAA. Psychiatric nursing in integrated wards accommodating both female and male patients: a historic pioneering reform initiative implemented by the Institute of Psychiatry, a Unit of the Federal University of Rio De Janeiro, Brazil. Iss Mental Health Nurs[Internet]. 2015[cited 2016 Sep 29];36(10):791-8. Available from: http://dx.doi.org/10.3109/01612840.2015.1043674 .

12. Ferreira MM. História do tempo presente: desafios[Internet]. Petrópolis: Cultura Vozes; 2000[cited 2016 Sep 29];94(3):111-24. Available from: http://hdl.handle.net/10438/6842

13. Meihy JCSB. Os novos rumos da História Oral: o caso brasileiro. Rev Hist[Internet]. 2006[cited 2015 Mar 11];155(2):191-203. Available from: http://www.revistas.usp.br/revhistoria/article/view/19041/21104

14. Paes MR, Maftum MA. Difficulties of nursing team of a general hospital in the care of patient with mental disorder. Rev Enferm UFPE[Internet]. 2013[cited 2015 Mar 11];7(9):5566-73. Available from: https://periodicos.ufpe.br/revistas/revistaenfermagem/ article/viewFile/13675/16566

15. Lima JML. Epilepsia: a abordagem clínica. Rev Port Clin Geral[Internet]. 2005[cited 2016 Sep 29];21(3):291-8. Available from: http://www.rpmgf.pt/ojs/index.php/rpmgf/article/view/10141/9878

16. Santos Jr A, Oliveira MC, Andrade TS, Freitas RR, Banzato CEM, Azevedo RCS, et al. Twenty years of electroconvulsive therapy in a psychiatric unit at a university general hospital. Trends Psychiatr Psychother[Internet]. 2013[cited 2017 Nov 08];35(3):229-33. Available from: http://dx.doi.org/10.1590/S2237-60892013000300010

17. White C, Pesut B, Rush K. Intensive care unit patients in the postanesthesia care unit: a case study exploring nurses' experiences. J Perianesth Nurs[Internet]. 2014[cited 2016 Sep 29];29(2):129-37 Available from : https://linkinghub.elsevier.com/retrieve/pii/ S1089-9472(13)00499-1

18. Guimarães AN, Borba LO, Larocca LM, Maftum MA. Mental health treatment according to the asylum model (1960 to 2000): nursing professionals' statements. Texto Contexto Enferm[Internet]. 2013[cited 2016 Sep 29];22(2):361-9. Available from: http:// www.scielo.br/pdf/tce/v22n2/en_v22n2a12.pdf

19. Macedo JP, Abreu MM, Fontenele MG, Dimenstein M. The regionalization of mental health and new challenges of the Psychiatric Reform in Brazil. Saúde Soc[Internet]. 2017[cited 2017 Nov 08];26(1):155-70. Available from: http://dx.doi.org/10.1590/ s0104-12902017165827 